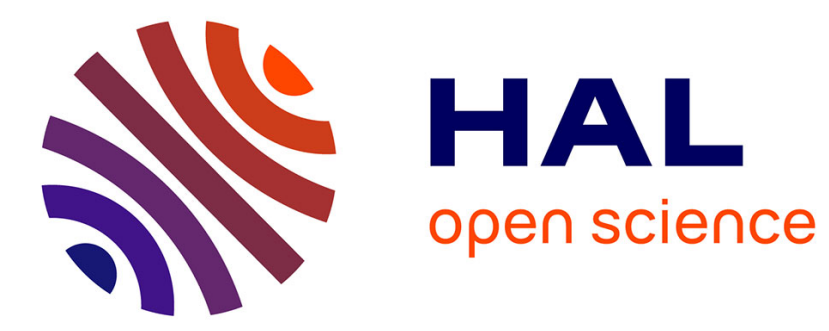

\title{
The Historical Evolution of Central Banking
}

Stefano Ugolini

\section{To cite this version:}

Stefano Ugolini. The Historical Evolution of Central Banking. Stefano Battilossi; Youssef Cassis; Kazuhiko Yago. Handbook of the History of Money and Currency, Springer Nature, 2018, 978-98110-0622-7. 10.1007/978-981-10-0622-7_31-1. hal-01887004

\section{HAL Id: hal-01887004 \\ https://hal-univ-tlse2.archives-ouvertes.fr/hal-01887004}

Submitted on 3 Oct 2018

HAL is a multi-disciplinary open access archive for the deposit and dissemination of scientific research documents, whether they are published or not. The documents may come from teaching and research institutions in France or abroad, or from public or private research centers.
L'archive ouverte pluridisciplinaire HAL, est destinée au dépôt et à la diffusion de documents scientifiques de niveau recherche, publiés ou non, émanant des établissements d'enseignement et de recherche français ou étrangers, des laboratoires publics ou privés. 


\title{
The Historical Evolution of Central Banking
}

\author{
Stefano Ugolini \\ University of Toulouse \\ (Sciences Po Toulouse and LEREPS)
}

\begin{abstract}
:
"Central banking" is what a central bank does, but the definition of "central bank" is less straightforward than it may appear at first sight. Following Ugolini (2017), this chapter defines central banking as the provision of public policies aimed at fostering monetary and financial stability, and surveys the historical evolution of such policies in the West from the Middle Ages to today. It shows that institutional equilibria mattered a lot in shaping the way stabilization policies were implemented: central banking evolved in markedly distinct ways in city states (like Venice, Amsterdam, Hamburg, Barcelona, or Genoa), centralized territorial polities (like Naples, Sweden, England, Austria, or France), or decentralized territorial polities (like the United States or the European Union). As a result, the historical evolution of central banking does not appear to have been driven by the "survival of the fittest", but rather by the constant adaptation of policymaking to changing political economy equilibria.
\end{abstract}




\section{1) Introduction}

What is central banking? Obviously, central banking is what a central bank does. But what is a central bank, and what does it do? Here, the answer is less straightforward. Today, the organizations falling under the label of "central banks" are not all alike and make a bunch of quite different things. Things get even more complicated if we move backwards in times: many of nowadays' central banks did not look like central banks when they were created, while other organizations that appeared to behave somewhat like central banks never evolved into proper central banks. The wording "central bank" started to be used to indicate the Bank of England only in the second half of the $19^{\text {th }}$ century; it had already been used before, but to indicate a different thing - i.e. the headquarters of a multi-branch commercial bank, not a privileged bank of issue.

In order to find a way out of this ontological conundrum, this chapter follows the strategy proposed by Ugolini (2017) and defines central banking as a family of public policies aimed at fostering monetary and financial stability, whose provision is nowadays generally (albeit not necessarily) performed by those organizations that we call central banks. This strategy allows tracking the evolution of central banking to a period well preceding the appearance of modern central banks. As a result, this chapter covers a much longer and broader spectrum than most available general surveys like e.g. Goodhart (1988), Capie et al. (1994), Giannini (2011), or Bordo and Siklos (2018). It focuses on a number of case studies that have been identified by previous scholarly research as relevant episodes in the evolution of central banking, and on which more abundant historical evidence is actually available. These include (in chronological order): Venice $\left(13^{\text {th }}-18^{\text {th }}\right.$ centuries); Barcelona $\left(15^{\text {th }}-19^{\text {th }}\right)$; Genoa $\left(15^{\text {th }}-18^{\text {th }}\right)$; Naples $\left(16^{\text {th }}-18^{\text {th }}\right)$; Amsterdam $\left(17^{\text {th }}-18^{\text {th }}\right)$; Hamburg $\left(17^{\text {th }}-19^{\text {th }}\right)$; Sweden $\left(17^{\text {th }}-19^{\text {th }}\right)$; England $\left(17^{\text {th }}-20^{\text {th }}\right)$; Austria $\left(18^{\text {th }}-19^{\text {th }}\right)$; France $\left(18^{\text {th }}-20^{\text {th }}\right)$; the United States $\left(18^{\text {th }}-\right.$ $\left.20^{\text {th }}\right)$; and the European Union $\left(20^{\text {th }}-21^{\text {st }}\right)$.

If central banking can legitimately be seen as public policy, then central banking cannot be analyzed separately from the political context in which it is implemented. The novelty of this survey consists of organizing historical evidence on the evolution of central banking in systematic relation to the institutional equilibria in which this evolution took place. The idea is to show that institutional frameworks were crucial in shaping the way the quest for monetary and financial stability was organized over time. The rest is structured as follows. After clarifying the adopted definition of central banking (Section 2), the chapter reviews the development of central banking in city states (Section 3), in centralized territorial polities (Section 4), as well as in decentralized territorial polities (Section 5). Some concluding remarks are drawn in the end (Section 6). 


\section{2) Conceptual Framework}

Ugolini (2017) proposes to see central banking as the joint provision of a set of public policies aimed at addressing market failures in the financial sector. Actually, there exist at least four rationales for public intervention in this domain: the first two can be associated to contemporary central banks' financial stability mandate, while the last two can be associated to their monetary stability mandate.

First, public intervention can be justified by the need of securing the efficiency of the "financial plumbing" of the economy, i.e. of regulating the management of the payment system (the system allowing for the transfer of funds from one point to any other point of an economy). As any other network infrastructure, the payment system is a natural monopoly: the supply of payment services is subject to scale economies, while their demand is subject to network externalities. In order to prevent monopolists from capturing rents, natural monopolies need to be regulated by public authorities. Regulation is also needed in view of the "essential" nature of the payment infrastructure, whose disruption can entail huge costs to real economic activity.

Second, the banking sector is inherently unstable in view of the extreme maturity and quality transformation business performed by banks. Banks are intermediaries funding their activity through demandable liabilities (deposits) and reinvesting into highly idiosyncratic long-term assets (loans): by construction, they are therefore prone to liquidity crises. An organization that is centrally situated within the payment system can (by virtue of its privileged position) create liquidity by lending to counterparties, and thus act as a lender of last resort in the event of liquidity crises. In view of its monopoly of crisis-time lending, such an organization enjoys a nonnegligible market power, and is therefore able to impose a number of conditions (regulatory standards) aiming at reducing risk-taking by counterparties.

Third, there exists a complementarity between the public sector's and the private sector's cash flows: the former is characteristically cash-strapped when the latter is cash-rich (after the administration's purchases of goods and services are paid for and before taxes are collected), and vice-versa. This complementarity naturally calls for the reciprocal smoothing of cash flows: the public sector can purchase on credit goods and services from the private sector, only to resorb such debt as soon as the latter will pay taxes. Because of its widespread acceptability, short-term debt eligible for tax payments naturally has a tendency to be used as a means of payment in transaction among third parties - or differently said, to be monetized. Debt monetization is a function that can well be provided by private intermediaries, who can advance funds to both public and private sector on the one hand while issuing monetary instruments to the private sector on the other hand. However, a disruption in the provision of this function by private intermediaries can entail substantial costs, as it can potentially jeopardize the public and private sectors' ability to conduct their regular activities. Hence, there exist good reasons for political authorities to secure the continuity of public and/or private debt monetization under any financial condition.

Fourth, public and private debt monetization by private intermediaries may not necessarily be optimal, as it can lead to excessive price volatility - which is obnoxious to real economic activity. In order to minimize such volatility, public authorities can intervene to stabilize the value of monetary instruments by both setting limits to private money creation 
and compensating for shortfalls in private money creation. This stabilization function is commonly known under the heading of monetary policy.

A priori, each one of these four functions might be conceivably provided separately from the others. In reality, however, this was seldom the case, as spillovers exist between them. As a matter of fact, 1) a banking organization issuing demandable liabilities (deposits or banknotes) that is centrally situated within an economy (for structural or juridical reasons) will naturally assume a leading role in the payment system; 2) the need to protect itself from counterparty risk will encourage the organization to take some regulatory role, which will be enhanced by its market power; 3) its lending activities will de facto consist of (public and/or private) debt monetization; and 4) the management of such lending activities will impact the value of the demandable liabilities issued by the organization, and thus de facto consist of monetary policymaking. In what follows, the historical development of mechanisms linking the issuance of credit money to lending operations will therefore be reviewed, with a particular focus on their implications in terms of public policy.

\section{3) Central Banking in City States}

\section{1: Central Banking in City States: Issues}

City states have been a pervasive presence in European geopolitics from the Middle Ages to the Napoleonic Wars. European city states typically originated from self-governing urban institutions, which gained increasing autonomy from feudal rulers in the central centuries of the Middle Ages. Among the many hundreds of such polities, the most famous ones were the so-called "merchant republics" - i.e., city states ruled by oligarchies of businessmen which had succeeded in becoming leading international trade centers (Lindemann 2015). In view of their relatively high degree of financial development, it is not surprising that the earliest attempts at elaborating central banking policies actually appeared in these polities.

Merchant republics featured an institutional equilibrium that allowed for practicing central banking directly through a branch of government. The monetary authorities of the merchant republics interacted with the same kinds of counterparties on both sides of their balance sheet: on the liabilities side, they predominantly borrowed from domestic businessmen (who were the ones that held and used the monetary instruments they issued), while on the assets side, they predominantly lent to a government that was tightly controlled by the very same businessmen. This perfect alignment of interests (Stasavage 2012) guaranteed the time consistency of monetary policy: public debt monetization could have inflationary outcomes only as long as these were justified by a superior goal (in general, militarily defending the commercial interests of the republic), and the ensuing inflation was expected to be compensated by deflation as soon as conditions came back to normality. This explains why, in these polities, central banking policies were implemented directly through a division of government or a state-owned public bank. 
If European merchant republics presented many common features, each one had its own peculiar institutional equilibrium. The example that was closest to the "ideal-type" of the merchant republic was Venice, a city state that had secured its full independence from territorial rulers since the early Middle Ages and that was run for centuries by a cohesive elite of businessmen. Amsterdam and Hamburg also were largely autonomous cities controlled by stable merchant oligarchies, but they were not fully sovereign states (they were formally part of, respectively, the United Provinces and the Holy Roman Empire). Barcelona long fought to retain its autonomy with respect to the Crown of Aragon, whose interference in local affairs gradually increased over the centuries. By contrast, Genoa was a de facto independent republic which was nonetheless characterized by harsh intestine infight within the ruling oligarchy (mostly consisting of feudal rather than bourgeois families). As the rest of this section will show, these institutional dissimilarities go a long way in explaining the different solutions found to the problems of domestic financial infrastructures.

\section{2: Venice}

Under many respects, the history of central banking in the West starts in late-medieval Venice. This should not be understood as meaning that Venetians "invented" central banking. Rather, it should be understood as meaning that Venetians were the first to experience on a large scale the problems to which central banking is supposed to be a solution, and were thus forced to find some tentative solutions earlier than elsewhere. The reason why this was the case was the early sophistication of Venice's payment infrastructure. In view of its unique geographical situation, the city's economy precociously experienced a high degree of monetization: as a result, by the late Middle Ages the deposit banking sector had already developed to an extent that was long unknown elsewhere. Already in the early $14^{\text {th }}$ century, bank transfers were widely used by the population in payment of up to relatively small sums, and were considered by jurisdiction as legal means to discharge debt (Mueller 1997). Such a pervasive role of bank transfers was very exceptional: as a matter of comparison, in another major late-medieval financial center like Florence (home to the most important international investment banks of the time), "dematerialized" payments played a significant role in intragroup transactions, but pure market transactions had to be cleared in cash (Padgett and McLean 2011). This means that Venice was probably the first place in the West to establish a truly modern payment system. This primacy did not come without strings attached, though: the price to pay for economizing on cash on a large scale was the inherent instability of fractional-reserve banking (Diamond and Dybvig 1983). And indeed, the history of Venetian banking was punctuated by a succession of violent liquidity crises jeopardizing the continuous provision of payment services.

Venetian political authorities were particularly concerned with potential disruptions in the domestic financial infrastructure. Besides entailing large negative effects on economic activity, such disruptions compromised the functioning of the "machine of the state" by preventing the government from smoothing its irregular cash flows. This was a particularly sensitive issue in Venice, where the sustenance of the metropolitan population strictly depended on the Republic's victualling activities: the government's inability to secure the 
provision of flour to the city at stable prices would have triggered social unrest. At the same time, Venetian authorities were also concerned with keeping - as much as possible - an armlength distance from the operation of the financial infrastructure. As a result, government intervention occurred only when private initiative was lacking. In the six centuries that separated the rise of its Mediterranean colonial empire from the fall of the Republic, such a situation occurred twice: first, in the early phases of consolidation of Venetian institutions following the colonial expansion $\left(13^{\text {th }}-14^{\text {th }}\right.$ centuries), and then at the time of their reorganization after the decline of its geopolitical power $\left(17^{\text {th }}-18^{\text {th }}\right.$ centuries $)$.

Starting from 1282, the Venetian state centralized most of its financial activities to the most important of its public victualling agencies, the Grain Office (Camera del Frumento). Besides its traditional mission to buy grain from importers and resell flour to the metropolitan population, the agency was now charged with the issuance of the floating debt on the security of streams of fiscal revenues. In addition, the Office was also allowed to collect deposits from the general public, both voluntary and forced (some types of funds, like e.g. dowries, had to be compulsorily deposited with it). The centralization of all these financial activities transformed the Grain Office into a sort of "state bank". The agency implemented the monetization of the public debt by borrowing from the general public on the security of future tax revenues. The deposit liabilities of the Office established themselves as the standard means of payment used both by merchants for big commercial transactions and by savers for petty day-by-day transactions (Mueller 1997).

Venice's early "state bank" worked rather successfully until the mid- $14^{\text {th }}$ century, when it started to get into troubles because of the bad performance of a number of subsidized loans extended to the private sector according to political criteria. Depositors' trust decreased as the Grain Office was forced to postpone the payment of interests on savings accounts, and the reform of 1365 actually terminated the "state bank" model. In the meantime, legislators had provided the status of legal money to deposits with chartered banks, and the private deposit banking sector had actually started to thrive. As a result, the government found it expedient to step back from direct intervention in the financial system, and externalized the tasks previously accomplished by the Grain Office (provision of payment services and public debt monetization) to the chartered private banks operating on the Rialto. In so doing, the government discharged onto the private sector all responsibilities for the occurrence of payment accidents as the ones that had occurred to the Grain Office (which had raised widespread criticism), but these benefits came at the cost of increased financial instability. As a matter of fact, private deposit banks fell victims to a long series of liquidity crises between the $14^{\text {th }}$ and the $16^{\text {th }}$ century, thus jeopardizing the working of the payment system and the government's ability to borrow. In view of the high costs of such disruptions for the economy as a whole, Venetian authorities were obliged to intervene with the aim of reducing instability. Over the decades, they developed a wide range of regulatory tools that were not unlike those in force nowadays. These included ex-ante interventions like the establishment of legal restrictions to operations, of specific supervisory bodies, and of disclosure requirements, but also ex-post interventions like lending of last resort (Ugolini 2017, pp. 120-131). As a result, despite its willingness to stay at arm's length from the financial sector, the government was actually obliged to provide some central banking functions during this period. Petitions 
for the creation of a public bank were repeatedly voiced in the aftermath of crises, but they were systematically rejected as long as an alternative was viable (Mueller 1997).

When the last chartered bank fell victim to the umpteenth depositors' run, however, the government had no other choice than taking back responsibility for the operation of the domestic financial infrastructure. After lengthy discussions, in 1587 the creation of a public bank (called Banco della Piazza di Rialto) was finally approved. This was not a state bank, but a public concession: a monopoly of deposit banking was created, but its management was delegated to a private concessioner under his full personal liability. Deposits were made attractive to the public by unpegging their value from the one of circulating specie, thus sheltering them from the general degradation the latter was experiencing at the time (Roberds and Velde 2016). Moreover, a forced demand for deposits was created by making bills of exchange compulsorily payable in bank. This was meant not only as a subsidy to the bank, but also as a supervisory device aimed at preserving the quality of circulating credit instruments (Ugolini 2017, pp. 55-61). These measures were apparently effective in securing the success of the Banco della Piazza (Luzzatto 1934; Tucci 1991).

Geopolitical factors, however, soon prompted new unintended changes to the design of Venetian monetary institutions. In 1619, the government faced difficulties in promptly repaying in specie purveyors that had delivered silver bullion to the Mint, and upon their request it made credits with the government transferable to third parties (a practice commonly adopted three centuries earlier by the Grain Office). Increasing military spending during the 1620s made the practice widespread, and thus transformed a provisional device into a stable one. Known as the Banco del Giro, the new mechanism (actually a division of the government) provided for the monetization of the public debt through the issuance of inconvertible money, which could be used (as an alternative to the one issued by the Banco della Piazza) for the payment of bills of exchange. Thus, the Banco del Giro was probably the first example of a purely fiduciary state-issued legal-tender money. Despite their inconvertibility, deposits with the new bank soon established themselves as the standard means of payment (also in view of the state's big role in the domestic economy) and thus displaced the payment business of the Banco della Piazza, which was eventually closed down in 1638. The Banco del Giro thus became the new "central bank" of Venice, and operated rather successfully until the fall of the Republic, when it was liquidated by the Napoleonic administration (Luzzatto 1934; Tucci 1991).

\section{3: Amsterdam and Hamburg}

Amsterdam and Hamburg were city-states with fairly similar institutional equilibria (Lindemann 2015), which faced the same kind of monetary problems at the more or less the same time, and which tried to address them with roughly similar solutions. In the last decades of the $16^{\text {th }}$ and early decades of the $17^{\text {th }}$ century, a massive wave of debasements (motivated by continuous warfare) took place in Europe. Debased coins started invading the circulation of international trade centers, thus compromising the fluidity of monetary transactions. In order to redress the quality of the circulating medium, in 1609 the City of Amsterdam opened a public exchange bank (the Wisselbank) whose mission consisted of withdrawing debased 
coins and releasing good-quality ones. As Venice had done some years earlier, Amsterdam created a forced demand for bank deposits by ruling that bills of exchange had to be compulsorily payable in bank. The measure was only partially successful, as the high fees imposed on the redemption of deposits into good specie discouraged potential depositors. In order to increase the attractiveness of bank money, in 1683 redemption fees were lowered, but the bank stopped paying in higher-quality coins than the ones it withdrew. The reform made bank money de facto inconvertible into the circulating medium, thus unpegging the value of the former from the latter. This strongly increased the popularity of bank money and allowed for the establishment of the Wisselbank as the pivot of the international monetary system (Quinn and Roberds 2009). Such a success allowed the government and governmentsponsored entities (esp. the Dutch East India Company) to monetize nonnegligible amounts of debt through the bank. Moreover, the bank started to indirectly behave as a lender of last resort, as it provided a liquidity backstop to the fund of mutual assistance that had been created in order to extend loans to cash-strapped merchant banks (Uittenbogaard 2009). In the last decades of the $18^{\text {th }}$ century, the United Provinces ran into serious military difficulties, and public debt monetization increased to such a scale that the value of bank money started to depreciate. As the country was transformed into a territorial monarchy by the Napoleonic troops, the municipal Wisselbank was closed down and replaced by the privately-owned Nederlandsche Bank (Quinn and Roberds 2016).

The Hamburger Bank (founded in 1619) was closely modelled along the Wisselbank. Its aim was the same: "cleaning" the domestic circulation from debased coins. However, the bank had a harder time than its Amsterdam model in stabilizing the value of its money. After many vicissitudes, in 1770 a great innovation was introduced: the bank pegged the value of its money to silver bullion rather than specie. In so doing, Hamburg introduced the first ingot standard in modern history, and became the leading market for silver in Europe (Roberds and Velde 2016). Moreover, the Hamburger Bank also developed a business of collateralized lending (on the security of commodities) to private counterparties, and during the 1763 crisis it acted as a lender of last resort for domestic merchant banks (Bindseil 2018). As the Free City of Hamburg survived the Napoleonic Wars, its bank also survived, until it was finally merged into the Reichsbank in 1875.

\section{4: Barcelona}

Barcelona is officially credited with having created the first public bank in Europe (Venice's Grain Office not having been designed as a banking organization proper). Founded in 1401, the Taula de Canvi was created primarily as the bank of the municipality in the context of the latter's conflicts with the Crown of Aragon (Riu 1979). In the early decades of its existence, the organization played an active role in the domestic payment system, as it opened current accounts to local bankers and extended credit by allowing them to overdraw. After facing a number of payment incidents as well as increasing difficulties in maintaining the convertibility of its money (jeopardized both by the rarefication of silver specie throughout Europe and by domestic depositors' frequent runs), in the second half of the $15^{\text {th }}$ century the Taula banned bankers from its customers. Although the actual effectiveness of the 
ban is unclear, it seems that the bank gradually refocused its business on its original mission as treasurer to the City, leaving aside all other competences in the domestic payment system. In this capacity, the bank financed the City's efforts to gain independence from the monarch in the event of the revolts of 1462, 1640, and 1713 (Usher 1943). The Taula provided the model for the many municipal banks that were created in the territories of the Crown of Aragon in the course of the $15^{\text {th }}$ and $16^{\text {th }}$ centuries, most of which survived until they were absorbed into the national central bank's branch network in the $19^{\text {th }}$ century (Roberds and Velde 2016).

\section{5: Genoa}

Well-known for their instability, Genoa's politics took a particularly dramatic turn after the loss of its naval power in the late $14^{\text {th }}$ century. Unable to restore the credibility of its huge public debt, in 1407 the Republic found no better solution than externalizing the management of both the debt and a number of major fiscal revenues to a "corporation of domestic bondholders". Founded as a fully private company held by the State's creditors, the Casa di San Giorgio proved an efficient device for granting the sustainability of the public debt (Fratianni 2006). Given the eminently fiscal nature of its mandate, it may not be surprising that San Giorgio's record in the monetary domain was less impressive. In the early decades of its life, the company actually opened current accounts to depositors, thus assuming a central role in the domestic payment system. At about the same time as the Taula de Canvi, however, San Giorgio was hit by the general rarefication of silver specie, and started to face serious difficulties in maintaining the convertibility of its money. Just like the Taula, San Giorgio hence reacted by withdrawing from banking activities altogether (Heers 1961). It was only in 1675 that the company reopened banking facilities and restarted issuing uniform bank money convertible into specie, thus reacquiring a central role in the domestic payment system (Felloni 2006; Gianelli 2006). After the reform, San Giorgio apparently lived a quiet existence until the French invaders deprived it from its fiscal competences in 1797, and was definitively closed down when the Republic was annexed by the Kingdom of Sardinia in 1815.

\section{4) Central Banking in Centralized Territorial Polities}

\section{1: Central Banking in Centralized Territorial Polities: Issues}

In the course of the early modern age, territorial monarchies generally underwent a process of centralization (encouraged by the spiraling costs of warfare). Besides securing a domestic monopoly on violence, rulers endeavored to centralize an increasing number of competences and to impose themselves as the sole source of political legitimacy in their territory. Unlike in the case of "merchant republics", in territorial monarchies the alignment of interests between the borrower and her creditors was far from warranted (Stasavage 2012). 
This explains why distrust of state-issued money was widespread among potential moneyholders. In order to reassure them about the time consistency of monetary policy, territorial monarchs found it expedient to externalize money creation to a formally independent organization. The organization would refinance itself from private depositors and banknoteholders on the one hand, while relending to the state on the other hand. Its administrators' autonomy with respect to the monarch was supposed to work as a guarantee that debt monetization would remain sustainable in the long term.

Territorial rulers' pursuit of the 'ideal-type' of the absolute monarchy was obviously confronted with the opposition of those that were set to lose from it. In the Habsburg monarchies of Spain and Austria, attempts at centralization met the resistance of the many peripheral institutional bodies (regional parliaments and municipalities) that had been inherited from preexisting polities; the same was also the case in Scandinavia. In England, the absolutist ambitions of the Stuarts were challenged by two revolutions, the second of which managed to stably introduce serious limitations to the Crown's competences. In France, the apparent success of the centralization process fostered by the Bourbons led to a spectacular accumulation of discontent, which eventually proved explosive in 1789.

The French Revolution and the many ensuing uprising of the first half of the $19^{\text {th }}$ century marked the end of the model of the absolute monarchy, and ushered in the model of the constitutional national government. Under this new model, the centralization of competences to the national government continued to be pursued, but was now counterbalanced by the rise in the power of antagonist national bodies like a parliament or an independent judiciary. The progressive extension of voting rights until the early decades of the $20^{\text {th }}$ century increased the legitimacy of the central government, making the rationale for a fully independent monetary authority less compelling than before. By the mid- $20^{\text {th }}$ century, money-issuing organizations had de jure or de facto become part of the public sector in most Western countries.

\section{2: Naples, Austria, and Sweden}

During the early modern period, a number of territorial monarchs that faced difficulties in establishing their legitimacy in the eyes of their subjects conferred issuing rights to some types of non-profit organizations run by a formally independent body. The organization would invest a sizeable amount of its resources in government debt, but its displayed autonomy with respect to the sovereign would facilitate the indirect refinancing of the public debt by depositors and money-holders. This strategy was inflected differently in a number of countries according to the different institutional equilibria in force.

The strategy was first pioneered in Naples in the second half of the $16^{\text {th }}$ century, when the Kingdom made part of the Crown of Spain. Spanish rulers were quite unpopular, and discontent often generated civil unrest (the most spectacular being the revolution of 1647). Because raising short-term funding from the public was difficult in this context, the Viceroy eyed the possibility of doing so through a number of popular charities that were already conducting a retail banking business at the time (the oldest one being the local Mount of Piety). On the one hand, the money issued by the seven chartered non-governmental 
organizations was declared eligible for tax payments, thus making it attractive to the public; while on the other hand, the organizations used part of the collected funds to extend loans to the government. Chartered banks of issue were formally independent, but they were strictly supervised by the Viceroyalty, which also appointed a representative to their boards. The expedient proved successful, and allowed the Neapolitan monetary system to withstand a number of shocks until the Napoleonic wars prompted its reorganization in 1808, with the creation of a monopolistic bank of issue called Banco delle Due Sicilie (De Rosa 1991; Balletta 2008; Velde 2018).

Spanish Habsburgs had a hard time securing short-term funding without resorting to some intermediary. For many decades, they were obliged to private intermediaries, esp. Genoese private bankers (Pezzolo and Tattara 2008; Drelichman and Voth 2011). The Austrian branch of the family long followed a similar strategy. In the context of a difficult debt restructuring, however, in 1705 a new strategy was endeavored, as the monarch approved the creation of a public bank formally controlled by the City of Vienna (the Wiener Stadtbanco). This time, it was the municipality's credit that was supposed to elicit depositors' trust, hence allowing for the refinancing of the Emperor's (and not of the City's) short-term debt. Although the administrators' actual independence at times proved to be more formal than substantial, the device worked reasonably well for almost a century, until it was finally disrupted by the financing of the Napoleonic wars. In 1816, it was replaced by a new privately-owned bank of issue, the Oesterreichische Nationalbank (Jobst and Kernbauer 2016).

The road to absolutism was much bumpier in Sweden, where it bred an uninterrupted confrontation between the monarch and the aristocracy (which held control of the parliament). An early attempt to create a royal bank (the Stockholms Banco, founded in 1657) failed after a few years also because of the attacks of the nobility. In the aftermath, the parliament managed to create its own bank (the Riksbank, founded in 1668). The Riksbank was involved in the financing of the public debt, but only as long as this was directed to goals that were compatible with the parliament's (read, the aristocrats') own interests. The result was a dual system of debt monetization (partly accomplished by the bank, and partly accomplished by the Treasury) that created much confusion in the domestic payment system. The duality came to an end after the Napoleonic wars, when the parliament definitively established its primacy on the monarch and the Riksbank eventually emerged as the country's sole monetary institution (Heckscher 1934; Ögren 2016).

\section{3: England}

The $17^{\text {th }}$ century was a period of great instability in England. After the second ousting of the Stuart dynasty in 1688, a quick normalization of the domestic political life could hardly be taken for granted. When in 1694 the new sovereigns found themselves in the urgent need to raise funds, they had to adopt the solution Genoa had engineered in 1407: resorting to a private company incorporated by creditors. Unlike San Giorgio, however, the newly-created Bank of England was originally designed as a temporary organization (set to expire after only eleven years), and was only destined to be in charge of one single portion of the public debt 
(Broz and Grossman 2004; Quinn 2008). Moreover, while to San Giorgio money creation was a secondary business (which was almost entirely shut down between 1444 and 1675), it was a primary one to the Bank of England: in its very first years of life, the Bank essentially had non-securitized long-term government loans on the assets side of its balance sheet, and redeemable banknotes on the liabilities side. Such an extreme maturity transformation business appears to have been very risky, and its success was far from warranted (Clapham 1944, I). Fortunately for the Bank, Londoners had already got accustomed by goldsmith bankers to the use of banknotes (Quinn 1997), and the demand for such means of payment was further increased by the famine of specie engendered by the "Great Recoinage" of 1696 (Desan 2014). Combined with the monopoly of joint-stock banking in London conferred by its charter, these circumstances helped the Bank establish itself at the center of the domestic payment system.

After the vagaries of the early $18^{\text {th }}$ century (the most spectacular of which being the South Sea scheme: Neal 1990), since 1751 the public debt was consistently reorganized and the Bank assumed a de facto monopolistic position in the provision of short-term funding to the government (von Philippovic 1911). At about the same time, the Bank started to develop substantially its discount activities, thus introducing the first lending facility ever offered to the private sector by a privileged money-issuing organization. In the meantime, since the de facto adoption of the gold standard in 1717 the Bank had assumed the role of gold marketmaker, which allowed it to stabilize the domestic monetary circulation (Ugolini 2017, pp. 230-234). Taken together, these three innovations redesigned the company into something much more akin to a modern central bank. By the time it entered the Napoleonic wars, the Bank had unquestionably become the ultimate manager of 1) the national payment system through its banknote issuance and clearing services, 2) the credit system through its lending facility, 3) the government's short-term funding through its role as state treasurer, and 4) the foreign exchange market through its role as gold market-maker.

In the course of the long $19^{\text {th }}$ century, the Bank of England perfected its joint provision of these four central banking functions. 1) When the Bank Act of 1844 (which made the Bank's charter perpetual) posed strict limits on the issuance of its banknotes, the Bank joined the London Clearing House and thus facilitated the use of its deposits as ultimate means of exchange in the domestic payment system (Martin-Holland 1910). 2) After usury ceilings were lifted, in the mid- $19^{\text {th }}$-century the Bank started to act as a lender of last resort - i.e., to provide unlimited access to its lending facility upon deposit of eligible collateral (Bignon et al. 2012). As a counterpart, in the absence of formal bank regulation, the Bank developed a sophisticated informal system of supervision of its London counterparties (Flandreau and Ugolini 2013; Ugolini 2017, pp. 131-143). 3) The Bank started to systematically offset the impact of variations in "autonomous factors" like Treasury balances, thus stabilizing money market interest rates (Wood 1939). 4) The Bank gradually adopted an official final target (foreign exchange rate stability) and an official monetary policy instrument (the market interest rate), thus developing a consistent monetary policy strategy (Bindseil 2004; Ugolini 2016).

Taken together, all these moves point to an increasing concern by the Bank about its "public responsibilities". Such a concern was already a matter of fact at least in the 1830s, but the formally private nature of the Bank (and the ensuing danger of conflicts of interests) was 
often used as an argument for curtailing its competences (Clapham 1944, II). Such an argument became obsolete during World War One, when the Treasury made it clear that the Bank was now expected to be a mere executor of the government's decisions. This paved the way to the Bank's eventual nationalization in 1946 (Capie et al. 1994).

By the interwar period, the Bank of England had come to be seen as the "ideal-type" of the modern central bank, and this idea was reinforced in the interwar as British money doctors started to advise countries throughout the world on why and how to create a central bank (Capie et al. 1994). As proved by the uneventful nature of its eventual internalization by the public sector, however, the $20^{\text {th }}$-century Bank had almost nothing in common with the design of the private company that had been originally established in 1694 .

\section{4: France}

Like almost any other early-modern territorial monarchy, France also met considerable difficulties in stabilizing its short-term borrowing. Under the "lame duck" regency of Philippe d'Orléans (1715-1723), John Law infamously tried to defy the (by then, already well established) principle that a state-controlled bank of issue could not thrive under an absolutist government. The eventual wreckage of Law's super-company (issuing inconvertible legaltender banknotes on the security of volatile streams of fiscal and monopoly revenues) may be interpreted as a confirmation of the principle. However, it is not inconceivable that the whole experiment had been pushed since its inception more as a temporary redistributive mechanism rather than as a permanent solution to the government's financial problems: as Law himself had acknowledged, the time consistency of the sovereign's action was a necessary precondition to the long-term success of a state bank (Neal 1990; Velde 2007).

After the shock of Law's bankruptcy, it took France half a century before a new banking charter was granted to a joint-stock company. This time, the principle was respected: the Caisse d'Escompte (founded in 1776) was a fully private bank, initially enjoying no privilege and set to be focused on lending to the private sector. Soon afterwards, however, its money was declared eligible for tax payments, and as a counterpart the bank was increasingly involved into government finance. After the outbreak of the Revolution, the Caisse failed to be turned into a national bank, and its large exposure to the state's ruined finances triggered its closure in 1793 (Roberds and Velde 2016).

The very same group of financiers that stood behind the Caisse d'Escompte formed, however, the backbone of the shareholders of the new Banque de France authorized by first consul Bonaparte in 1800. Of course, Napoleon expected the new company to provide useful services to the state, although under slightly different respects than the monarchs of the ancien régime. On the one hand, the bank was expected to create an efficient payment infrastructure covering the whole territories ruled by France. This would have allowed establishing a reliable payment system and, consequently, improving the management of the Treasury's cash flows (Prunaux 2016). On the other hand, the bank was expected to support government finances only indirectly, by maintaining stable conditions in the money market under whatever circumstance. To the contrary, the bank was not asked to invest directly large amounts of its resources in the public debt (Ramon 1929). In the century that followed the fall 
of Napoleon, the Banque de France did actually operate along the very lines of conduct the emperor had originally drawn for it. It developed the largest branch network of Europe, providing payment, lending-of-last-resort, and supervisory facilities to the most remote corners of the country (Jobst 2010; Bignon and Avaro 2017); it defended the stability of domestic interest rates by every possible means (Bignon et al. 2012; Bazot et al. 2016); and most notably, it maintained its direct holdings of government debt at remarkably low levels (Jobst and Ugolini 2016), to the point of pushing the restored monarchs to create alternative mechanisms for securing the absorption of government loans (the Caisse des Dépôts et Consignations, founded in 1816 and put under the control of the parliament: Boudet 2006). As a result, the Banque de France followed in the $19^{\text {th }}$ century a trajectory that was parallel but not convergent with respect to the English model (Bignon and Flandreau 2018). Even the circumstances of its eventual nationalization were different than those of the Bank of England, as this occurred after the government had been obliged to bailout the bank in order to cover the losses it had suffered on its foreign exchange reserves (Accominotti 2009).

\section{5) Central Banking in Decentralized Territorial Polities}

\section{1: Central Banking in Decentralized Territorial Polities: Issues}

As pointed out by theories of fiscal federalism (see e.g. Alesina and Spolaore 2003), the question of the optimal provision of public policy assumes different contours in contexts where the level of government to which policymaking is delegated becomes an endogenous variable. In such contexts, reaching an efficient provision is remarkably more complicated, as the basic issue of the "equilibrium of power" between different interest groups is doubled with the additional issue of the "equilibrium of power" between different levels of jurisdiction.

Although none of the stories told in the previous paragraphs was totally exempt from this kind of issues, the latter manifested themselves on a truly macroscopic scale only in the case of federations or supranational unions, in which interest groups were really transversal and were not necessarily embodied by the one or the other subfederal jurisdiction. Because of the complexity (and unpredictability) of the outcomes of collective bargaining, the evolution of central banking has been particularly tortuous in these institutional contexts. Currently, the two largest monetary areas in the world (the United States and the European Monetary Union) are both the results of this type of process.

\section{2: The United States}

The history of the United States has always been (and still is) characterized by the dynamic coexistence of centripetal and centrifugal forces. As a matter of fact, the monetary realm was one in which clashes were most violent. Conflicts predated the writing of the 
federal pact, as they were a direct consequence of Britain's colonial policy. Before independence, British rulers had kept the right of coining full-bodied specie for themselves. In the meantime, they had allowed each single colonial authority to issue its own inconvertible money in order to facilitate the management of cash flows, and had imposed rules on how monetization should be conducted; however, they had also made clear that they would bear no responsibility for any accident that might have occurred. As the performance of money creation varied widely across colonies, each would-be state was encouraged to "keep the house in order" on its own. When the War of Independence erupted, the first federal body that was created (the Continental Congress) found serious difficulties in financing the war effort, as no fiscal revenue had been transferred to it. Following the collapse in the value of the inconvertible money it had issued, in 1782 the Congress backed the foundation of the Bank of North America (a joint-stock company modelled along the original Bank of England of 1694); however, the states refused to make the new bank's money eligible for tax payments, thus killing the project. In 1787, the Constitutional Convention meant to draw a definite line between the monetary competences of the federal and state level: states would be prevented from issuing money directly, but maintained the right to charter local banks of issue; while Congress would have the exclusive right to "coin money and regulate the value thereof" viz., to strike metallic specie. While the meaning of such wording was apparently straightforward to its writers, its correct interpretation was the subject of many decades of harsh disputes (only definitively settled by the Supreme Court in the 1880s) on whether the Constitution provided federal authorities with the right to undertake or regulate the issuance of paper money (Timberlake 1993; Grubb 2003).

Given the unclear legality of federal interventions in the banking realm, the monetary solutions sponsored by Congress proved fragile. After the failed attempt to create a Bank of North America, two Banks of the United States were provided a twenty-year federal charter (in 1791 and 1816 respectively). Both were Philadelphia-based joint-stock companies modelled along the Bank of England; both operated actively to create a national payment system; both provided lending facilities to the public; both acted as treasurers to the federal government; both acted successfully to clean the domestic circulation from wartime inconvertible paper money. For all their merits, however, both faced harsh criticism from the political opponents of centralization, and failed to secure the renewal of their charter when this came to expiration (Catterall 1903; Wettereau 1942; Knodell 2016; Javat 2017).

In the meantime, states had not refrained from using their prerogatives in the domain of banking. Banks of issue were chartered and regulated at the state level, and regulation varied considerably across the country. During the first half of the $19^{\text {th }}$ century, basically all of the modern tools of banking regulation were invented or developed by different US states. Among these, the principle that the issuance of banknotes should be collateralized by a given amount of public debt became established almost everywhere (Rockoff 1991). This indirect strategy for pursuing government debt monetization through regulation would later become the cornerstone of the National Banking System created in 1863-1865 (Ugolini 2017, pp. 143148 and 196-198).

The shifting of political equilibria during the Civil War allowed for the centralization of a number of banking competences to the federal level. Concerning money creation, the Treasury resorted massively to the issuance of legal-tender notes (the "greenbacks") in order 
to finance the war, and henceforth retained its issuing rights for more than a century. Concerning banking regulation, a dual system was created: on the one hand, national banks were regulated at the federal level, and were henceforth authorized to issue banknotes on the security of federal debt; on the other hand, state banks remained regulated at the state level, and were allowed to issue banknotes only at prohibitive costs (note that, despite their official labelling, national banks did not operate throughout the federation, as interstate branching remained prohibited). Despite creating a pyramidal banking system through the introduction of reserve requirements (White 1983), the reforms did not provide for a countercyclical mechanism to stabilize the payment and credit system in times of crises. The Treasury partially compensated for this lack by moving its liquid assets across national banks, but only on a limited scale (Taus 1943). Private clearinghouses developed interbank lending facilities in order to compensate for the lack of a lender of last resort, but these were only accessible to clearinghouse members, i.e. only to a minority of banks (Jaremski 2018).

The increasing cost of banking crises in the ensuing decades became a matter of popular concern, and calls for reform started to be voiced. In particular, the dramatic crisis of 1907 opened a window of opportunity that a coalition of different interest groups managed to seize (Broz 1997). In 1913, the Federal Reserve System was created. Rather than the transposition of the English model, it was an incremental development of the National Banking System. The new organization was conceived as a user-owned facility, held by the very commercial banks which joined the System. Because interstate branching was a political taboo, the banking system continued to be fragmented; in order to bring the new facility as close as possible to its users, twelve fully independent Federal Reserve Banks were created, whose areas of competence closely followed the structure of the pyramidal reserve system designed by the Acts of 1863-1865 (Jaremski and Wheelock 2017). Moreover, as a substantial share of state banks did not find it worthwhile to join, the dual regulatory system put in place during the Civil War remained unscathed: as it had been the case for clearinghouses, access to the Fed's payment and lending facilities remained restricted to members (Calomiris et al. 2016).

The creation of the Fed was certainly a further step towards centralization in the banking realm, but not the definitive one. The twelve independent Reserve Banks could fix their monetary stance regardless of the others, and this created serious coordination problems during crises (Meltzer 2003-2010, I). Moreover, the dual nature of the banking system impeded Reserve Banks from extending lending of last resort to nonmember banks (Bordo and Wheelock 2013). Taken together, these limitations produced a reaction to the banking crises of the 1930s that was clearly suboptimal. Dissatisfaction motivated the Banking Acts of 1933-1935, which transformed the Fed into a de facto federal agency. The New Deal reforms particularly addressed the coordination problem, by centralizing the conduct of monetary policy to the Federal Reserve Board in Washington. They did not, however, address the question of the duality of the regulatory system, which still persists to date.

\section{3: The European Union}

Formally, the European Union is (to date) the only case in history of a supranational union. Such a uniqueness must not be exaggerated, as the Union might legitimately be seen as 
a sort of "federation in the making" like a number of nowadays' federations happened to be in the past. That said, the experience of European monetary unification was unique in that it consisted of federating a number of preexisting national central banks rather than imposing a new organization on top of them. Differently put, the process did not consist of managing the conflict between competing jurisdictions as in the case of the United States, but rather of coordinating the action of a number of peer jurisdictions maintaining both their full formal sovereignty and the theoretical option to leave the system.

The process of European monetary unification started in the 1970s, when the demise of Bretton Woods forced Europeans to continue the system on a regional basis (Mourlon-Druol 2012). The recurrent foreign exchange crises proved costly to European economies and jeopardized the process of commercial integration initiated in the 1950s. As the viability of a system of fixed but adjustable foreign exchange parities was proving incompatible with free capital mobility, European countries started to eye the possibility of "merging" their currencies into a single one. In order to minimize the risk that discussions about the distributional effects of unification might derail the process, negotiations were always kept focused on technical issues (James 2012). Technical difficulties were actually far from marginal, as monetary structures and practices differed substantially across countries. A long process of convergence was set in motion; a number of differences still persisted in the late 1990 s, yet not to the point of compromising the viability of a monetary policy coordinated at the centralized level but implemented at the decentralized one (Forssbæck and Oxelheim 2003; Galvenius and Mercier 2011).

National central banks had already been granted independence by their governments before the creation of Eurosystem, but independence was made a precondition for membership. This was consistent with the technocratic nature of the project, that was supposed to be viable only in isolation with respect to political interferences. The European Central Bank (established in 1998) was given charge for the coordination in the management of the payment infrastructure (through the creation of the TARGET system: Kokkola 2010) and in monetary policymaking. By contrast, banking supervision and (of course) the role of state treasurer stayed with national authorities. The fact that supervision remained confined to the decentralized level was not perceived as an issue in the beginning: financial regulation had been on the path to homogenization since the 1980s, and there was no consensus on the fact that the central bank was the best candidate for conducting supervision (Masciandaro and Quintyn 2016). The crisis started in 2007 (entailing a number of big bailouts of banks by national fiscal authorities) showed the limits of this approach, and brought back to light all the political dimensions of monetary unification that had been meticulously hidden until that moment (James 2012). In 2012, member countries agreed on a number of reforms of the Eurozone's fiscal and monetary governance: these included the creation of the so-called Banking Union, i.e. a single supervisory mechanism and a single resolution mechanism for failing banks. As a result, the European Central Bank was eventually entrusted with the supervision of bigger Eurozone banks, while smaller ones were left under the control of national central banks. Curiously, this produced (for the first time in Europe) a dual supervisory system that somewhat echoes the American one. 


\section{6) Conclusions}

This chapter has briefly surveyed available historical evidence on a number of relevant episodes in the evolution of the provision of monetary and financial stability. The results appear to suggest that in central banking one size does not fit all, and that the evolution of central banking did not take place according to the principle of the "survival of the fittest" (Roberds and Velde 2016). On the one hand, the "extinction" of some organizational solutions (like e.g. the early public banks created by European city states) appears to have been tied to the shake-up of the institutional equilibria in which they operated rather than to their inherent suboptimality. On the other hand, although some specific organizational solutions (like e.g. the Bank of England) were actually seen as "models" to some extent, the development of central banking appears to have been mostly determined by domestic political economy factors rather than by foreign inspiration. Different paths towards monetary and financial stability have been pursued across time and space, and experimentation seems to go on today. After all, central banking is policymaking, and policymaking does not take place in a vacuum: in the future, it will presumably continue to coevolve with institutional equilibria as much as it did in the past.

\section{References}

- O. Accominotti (2009) 'The Sterling Trap: Foreign Reserve Management at the Bank of France, 1928-1936', European Review of Economic History, XIII, 349-376.

- A. Alesina and E. Spolaore (2003) The Size of Nations (Cambridge MA: MIT Press).

- F. Balletta (2008) La circolazione della moneta fiduciaria a Napoli nel Seicento e nel Settecento (1587-1805) (Naples: Edizioni Scientifiche Italiane).

- G. Bazot, M. D. Bordo, and E. Monnet (2016) 'International Shocks and the Balance Sheet of the Bank of France under the Classical Gold Standard', Explorations in Economic History, LXII, 87-107.

- V. Bignon and M. Avaro (2017) 'Socially Embedded Money Creation: Monetary Policy and Bank of France Counterparty Risk Management in Late NineteenthCentury France', working paper.

- V. Bignon and M. Flandreau (2018) 'The Other Way: A Narrative History of the Bank of France' in R. Edvinsson, T. Jacobson and D. Waldenström (eds.), Sveriges Riksbank and the History of Central Banking (Cambridge: Cambridge University Press), 206-241. 
- V. Bignon, M. Flandreau, and S. Ugolini (2012) 'Bagehot for Beginners: The Making of Lending-of-Last-Resort Operations in the Mid-19 ${ }^{\text {th }}$ Century', Economic History Review, LXV, 580-608.

- U. Bindseil (2004) Monetary Policy Implementation: Theory, Past, Present (Oxford: Oxford University Press).

- U. Bindseil (2018) 'Pre-1800 Central Bank Operations and the Origins of Central Banking', working paper.

- M. D. Bordo and P. L. Siklos (2018) 'Central Banks: Evolution and Innovation in Historical Perspective' in R. Edvinsson, T. Jacobson and D. Waldenström (eds.), Sveriges Riksbank and the History of Central Banking (Cambridge: Cambridge University Press), 26-89.

- M. D. Bordo and D. C. Wheelock (2013) 'The Promise and Performance of the Federal Reserve as Lender of Last Resort, 1914-1933' in M. D. Bordo and W. Roberds (eds.), The Origins, History, and Future of the Federal Reserve: A Return to Jekyll Island (New York: Cambridge University Press), 59-98.

- J.-F. Boudet (2006) La Caisse des dépôts et consignations: histoire, statut, fonction (Paris: L'Harmattan).

- J. L. Broz (1997) The International Origins of the Federal Reserve System (Ithaca and London: Cornell University Press).

- J. L. Broz and R. S. Grossman (2004) 'Paying for Privilege: The Political Economy of Bank of England Charters, 1694-1844', Explorations in Economic History, XLI, 4872.

- C. W. Calomiris, M. S. Jaremski, H. Park, and G. Richardson (2016) 'Liquidity Risk, Bank Networks, and the Value of Joining the Federal Reserve System', working paper.

- F. Capie, C. A. E. Goodhart, and N. Schnadt (1994) 'The Development of Central Banking' in F. Capie, C. A. E. Goodhart, S. Fischer, and N. Schnadt (eds.), The Future of Central Banking: The Tercentenary Symposium of the Bank of England (Cambridge: Cambridge University Press), 1-231.

- R. C. H. Catterall (1903) The Second Bank of the United States (Chicago: University of Chicago Press).

- J. Clapham (1944) The Bank of England: A History (Cambridge: Cambridge University Press). 
- L. De Rosa (1991) 'Banchi pubblici, banchi privati e monti di pietà a Napoli nei secoli XVI-XVIII' in Banchi pubblici, banchi privati e monti di pietà nell'Europa preindustriale (Genoa: Società Ligure di Storia Patria), 497-512.

- C. Desan (2014) Making Money: Coin, Currency, and the Coming of Capitalism (Oxford: Oxford University Press).

- D. W. Diamond and P. H. Dybvig (1983) 'Bank Runs, Deposit Insurance, and Liquidity', Journal of Political Economy, XCI, 401-419.

- M. Drelichman and H.-J. Voth (2011) 'Lending to the Borrower from Hell: Debt and Default in the Age of Philip II', Economic Journal, CXXI, 1205-1227.

- G. Felloni (2006) 'Il credito all'erario e ai privati: forme ed evoluzioni' in G. Felloni (ed.), La Casa di San Giorgio: il potere del credito (Genoa: Società Ligure di Storia Patria), 155-164.

- J. Forssbæck and L. Oxelheim (2003) Money Markets and Politics: A Study of European Financial Integration and Monetary Policy Options (Cheltenham: Edward Elgar).

- M. Fratianni (2006), 'Government Debt, Reputation and Creditors' Protections: The Tale of San Giorgio', Review of Finance, X, 487-506.

- M. Flandreau and S. Ugolini (2013) 'Where It All Began: Lending of Last Resort and Bank of England Monitoring during the Overend-Gurney Panic of 1866' in M. D. Bordo and W. Roberds (eds.), The Origins, History, and Future of the Federal Reserve: A Return to Jekyll Island (New York: Cambridge University Press), 113-161.

- M. Galvenius and P. Mercier (2011) 'The Story of the Eurosystem Framework' in P. Mercier and F. Papadia (eds.), The Concrete Euro: Implementing Monetary Policy in the Euro Area (Oxford: Oxford University Press), 115-214.

- G. Gianelli (2006) 'La riforma monetaria genovese del 1671-75 e l'apertura del banco di moneta corrente' in G. Felloni (ed.), La Casa di San Giorgio: il potere del credito (Genoa: Società Ligure di Storia Patria), 121-142.

- C. Giannini (2011) The Age of Central Banks (Cheltenham: Edward Elgar).

- C. A. E. Goodhart (1988) The Evolution of Central Banks (Cambridge MA and London: MIT Press).

- F. Grubb (2003) 'Creating the U.S. Dollar Currency Union, 1748-1811: A Quest for Monetary Stability or a Usurpation of State Sovereignty for Personal Gain?', American Economic Review, XCIII, 1778-1798. 
- E. F. Heckscher (1934) 'The Bank of Sweden in Its Connection with the Bank of Amsterdam' in J. G. Van Dillen (ed.), History of the Principal Public Banks (The Hague: Nijhoff), 161-200.

- J. Heers (1961) Gênes au XVe siècle: activité économique et problèmes sociaux (Paris: SEVPEN).

- H. James (2012) Making the European Monetary Union (Cambridge MA and London: Belknap Press).

- M. Jaremski (2018) 'The (Dis)Advantages of Clearinghouses before the Fed', Journal of Financial Economics, CXXVII, 435-458.

- M. Jaremski and D. C. Wheelock (2017) 'Banker Preferences, Interbank Connections, and the Enduring Structure of the Federal Reserve System', Explorations in Economic History, LXVI, 21-43.

- A. Javat (2017) 'An Analysis of the Balance Sheet of the First Bank of the United States', working paper.

- C. Jobst (2010) 'Gouverner une banque centrale décentralisée: l'exemple austrohongrois (1847-1914)' in O. Feiertag and M. Margairaz (eds.), Gouverner une banque centrale: du XVIIe siècle à nos jours (Paris: Albin Michel), 113-140.

- C. Jobst and H. Kernbauer (2016) The Quest for Stable Money: Central Banking in Austria, 1816-2016 (Frankfurt am Main: Campus).

- C. Jobst and S. Ugolini (2016) 'The Coevolution of Money Markets and Monetary Policy, 1815-2008' in M. D. Bordo, Ø. Eitrheim, M. Flandreau, and J. F. Qvigstad (eds.) Central Banks at a Crossroads: What Can We Learn from History? (New York: Cambridge University Press), 145-194.

- J. Knodell (2016), The Second Bank of the United States: "Central” Banker in an Era of Nation Building, 1816-1836 (London and New York: Routledge).

- T. Kokkola (2010) The Payment System: Payments, Securities and Derivatives, and the Role of the Eurosystem (Frankfurt am Main: European Central Bank).

- M. Lindemann (2015) The Merchant Republics: Amsterdam, Antwerp, and Hamburg, 1648-1790 (New York: Cambridge University Press).

- G. Luzzatto (1934) 'Les banques publiques de Venise (siècles XVI-XVIII)' in J. G. Van Dillen (ed.), History of the Principal Public Banks (The Hague: Nijhoff), 39-78.

- R. Martin-Holland (1910) 'The London Bankers Clearing House' in The English Banking System (Washington DC: National Monetary Commission), 267-294. 
- D. Masciandaro and M. Quintyn (2016) 'The Governance of Financial Supervision: Recent Developments', Journal of Economic Surveys, XXX, 982-1006.

- A. H. Meltzer (2003-2010) A History of the Federal Reserve (Chicago: University of Chicago Press).

- E. Mourlon-Druol (2012) A Europe Made of Money: The Emergence of the European Monetary System (Ithaca NY: Cornell University Press).

- R. C. Mueller (1997) The Venetian Money Market: Banks, Panics, and the Public Debt, 1200-1500 (Baltimore: Johns Hopkins University Press).

- L. Neal (1990) The Rise of Financial Capitalism: International Capital Markets in the Age of Reason (Cambridge: Cambridge University Press).

- A. Ögren (2016) 'From Parliamentary Institution to a Modern Central Bank: The Bank of Sweden' in O. Feiertag and M. Margairaz (eds.), Les banques centrales et l'Étatnation (Paris: Presses de Sciences Po), 49-72.

- J. F. Padgett and P. D. McLean (2011) 'Economic Credit in Renaissance Florence', Journal of Modern History, LXXXIII, 1-47.

- L. Pezzolo and G. Tattara (2008) “Una Fiera Senza Luogo”: Was Bisenzone an International Capital Market in Sixteenth-Century Italy?', Journal of Economic History, LXVIII, 1098-1122.

- E. von Philippovich (1911) History of the Bank of England and Its Financial Services to the State (Washington DC: National Monetary Commission).

- E. Prunaux (2016) 'Le rôle de le Banque de France dans l'édification de l'État napoléonien' in O. Feiertag and M. Margairaz (eds.), Les banques centrales et l'Étatnation (Paris: Presses de Sciences Po), 99-135.

- S. Quinn (1997) 'Goldsmith-Banking: Mutual Acceptance and Interbanker Clearing in Restoration London', Explorations in Economic History, XXXIV, 411-432.

- S. Quinn (2008) 'Securitization of Sovereign Debt: Corporations as a Sovereign Debt Restructuring Mechanism in Britain, 1694 to 1750 ', working paper.

- S. Quinn and W. Roberds (2009) 'An Economic Explanation of the Early Bank of Amsterdam, Debasement, Bills of Exchange and the Emergence of the First Central Bank' in J. Atack and L. Neal (eds.), The Origins and Development of Financial Markets and Institutions: From the Seventeenth Century to the Present (Cambridge and New York: Cambridge University Press), 32-70. 
- S. Quinn and W. Roberds (2016) 'Death of a Reserve Currency', International Journal of Central Banking, XII, 63-103.

- G. Ramon (1929) Histoire de la Banque de France d'après les sources originales (Paris: Grasset).

- M. Riu (1979) 'Banking and Society in Late Medieval and Early Modern Aragon' in The Dawn of Modern Banking (New Haven and London: Yale University Press), 131168.

- W. Roberds and F. R. Velde (2016) 'Early Public Banks' in D. Fox and W. Ernst (eds.) Money in the Western Legal Tradition: Middle Ages to Bretton Woods (Oxford: Oxford University Press), 321-355 and 465-488.

- H. Rockoff (1991) 'Lessons from the American Experience with Free Banking' in F. Capie and G. E. Wood (eds.), Unregulated Banking: Chaos or Order? (Basingstoke: Macmillan), 73-109.

- D. Stasavage (2012) States of Credit: Size, Power, and the Development of European Polities (Princeton and Oxford: Princeton University Press).

- E. R. Taus (1943) Central Banking Functions of the United States Treasury, 17891941 (New York: Columbia University Press).

- R. H. Timberlake (1993) Monetary Policy in the United States: An Intellectual and Institutional History (Chicago and London: Chicago University Press).

- U. Tucci (1991) 'Il banco pubblico a Venezia' in Banchi pubblici, banchi privati e monti di pietà nell'Europa preindustriale (Genoa: Società Ligure di Storia Patria), 309-325.

- S. Ugolini (2016) 'Liquidity Management and Central Bank Strength: Bank of England Operations Reloaded, 1889-1910', Norges Bank Working Paper, 10/2016.

- S. Ugolini (2017), The Evolution of Central Banking: Theory and History (London: Palgrave Macmillan).

- R. Uittenbogaard (2009) 'Lending by the Bank of Amsterdam (1609-1802)' in M. Van Nieuwkerk (ed.), The Bank of Amsterdam: On the Origins of Central Banking (Arnhem: Sonsbeek), 120-131.

- A. P. Usher (1943) The Early History of Deposit Banking in Mediterranean Europe, I, (Cambridge MA: Harvard University Press).

- F. R. Velde (2007) 'John Law's System', American Economic Review, XCVII, 276279. 
- F. R. Velde (2018) 'The Neapolitan Banks in the Context of Early Modern Public Banks' in L. Costabile and L. Neal (eds.), Financial Innovation and Resiliency: A Comparative Perspective on the Public Banks of Naples (1462-1808) (London: Palgrave Macmillan).

- J. O. Wettereau (1942) 'The Branches of the First Bank of the United States', Journal of Economic History, II (Supplement), 66-100.

- E. N. White (1983) The Regulation and Reform of the American Banking System, 1900-1929 (Princeton: Princeton University Press).

- E. Wood (1939) English Theories of Central Banking Control, 1819-1858 (Cambridge MA: Harvard University Press). 